\title{
HUBUNGAN BERAT BAYI DENGAN ROBEKAN PERINEUM PADA PERSALINAN FISIOLOGIS DI RB LILIK SIDOARJO
}

\author{
Fritria Dwi Anggraini \\ Fakultas Keperawatan dan Kebidanan \\ Universitas Nahdlatul Ulama Surabaya - Jl Smea 57 Surabaya \\ Email : fritria@unusa.ac.id
}

\begin{abstract}
RB Lilik. Childbirth often results in injury or birth canal called the perineal robekan, birth weight effect on stretching the perineum, but the robekan perenium still occur despite the child born today is not too large. The purpose of this study to analyze the relationship with birth weight at delivery perineal robekan in RB Lilik .Research design was analytic: cross sectional. The population were the entire maternal physiological in BPS Lilik Farida Kedurus Sidoarjo in June 2013 by 27 people then. Sample were 25 responden. The independent variable birth weight and the dependent variable robekan of the perineum. Sampling technique performed probability sampling with simple random sampling technique. Data were analyzed using the Mann-whtney statistical test using SPSS for Windows and the level of significance $\alpha=0.05$. Results of Mann-Whitney statistical test showed $\rho=0.004$ means that there is a relationship between birth weight with perineal robekan at physiological childbirth. Conclusions delivery with birth weight effect on stretching the perineum which can lead to robekan of the perineum.
\end{abstract}

\begin{abstract}
Abstrak: Hubungan Berat Badan Bayi Lahir Dengan Robekan Perineum Pada Persalinan Fisiologis Di RB Lilik. Persalinan seringkali mengakibatkan perlukaan jalan lahir atau yang disebut dengan ruptur perineum, Berat badan bayi lahir berpengaruh pada peregangan perineum, namun ruptur perenium masih terjadi meskipun bayi yang di lahirkan tidak terlalu besar. Tujuan penelitian ini menganalisa hubungan berat badan bayi lahir dengan robekan perineum pada persalinan fisiologis di RB Lilik .

Desain penelitian yang digunakan adalah analitik dengan pendekatan yang digunakan adalah cross sectional. Populasi dalam penelitian adalah seluruh ibu bersalin fisiologis di RB Lilik Kedurus Sidoarjo pada bulan Juni 2013 sebesar 27 orang kemudian diambel sampel sebesar 25 orang. Variabel bebas berat bayi lahir dan variabel terikat robekan perineum. Tehnik sampling dilakukan secara probability sampling dengan teknik simple random sampling. Data dianalisis dengan menggunakan uji statistik Mann-whtney dengan menggunakan SPSS for Windows dan tingkat signifikasi $\alpha=0,05$

Hasil uji statistik mann-Whitney menunjukkan $\rho=0,004$ berarti ada hubungan antara berat badan bayi lahir dengan ruptur perineum pada persalinan fisiologis. Simpulan persalinan dengan berat badan bayi lahir berpengaruh pada peregangan perineum yang dapat menyebabkan terjadinya robekan perineum.
\end{abstract}

Kata Kunci ; Berat bayi, robekan perineum 



\section{PENDAHULUAN}

Persalinan seringkali mengakibatkan perlukaan jalan lahir atau yang disebut dengan ruptur perineum baik perlukaan ringan sampai terjadi luka yang luas dan berbahaya (Prawirohardjo, 2007). Ruptur Perineum dapat terjadi karena ruptur spontan maupun ruptur di sengaja (episiotomi). Berat badan bayi lahir berpengaruh pada peregangan perineum sehingga pada perineum mudah terjadi ruptur (Cuningham, 2005). Tetapi pada lahan praktek ruptur perenium masih terjadi meskipun bayi yang di lahirkan tidak terlalu besar, baik itu ruptur spontan maupun ruptur yang disengaja (episiotomi). Menurut pelatihan klinik APN, 2008 ruptur spontan pada vagina atau perineum dapat terjadi pada saat kepala dan bahu dilahirkan. Robekan akan meningkat jika bayi di lahirkan terlalu cepat dan tidak terkendali. Episiotomi merupakan tindakan yang menyebabkan ruptur pada perineim. Menurut (varney, 2008) perenium harus segera di evaluasi sebelum waktu persalinan untuk mengetahui panjangnya, ketebalan dan distensibilitasnya. Evaluasi ini membantu menentukan tindakan episiotomi, akan tetapi episiotomi masih tetap menjadi tindakan yang kontroversi karena asuhan sayang ibu dan tidak semua persalinan memerlukannya.

Di seluruh dunia pada tahun 2009 terjadi 2,7 juta kasus ruptur perineum pada ibu bersalin. Hasil studi penelitian pada tahun 2009 - 2010 pada beberapa Propinsi di Indonesia didapatkan bahwa satu dari lima ibu bersalin yang mengalami ruptur perineum akan meninggal dunia dengan persentase (21,74\%) (Puslitbang Bandung, 2011). Prevalensi ibu bersalin yang mengalami ruptur perineum di Indonesia pada golongan umur 25 - 30 tahun yaitu $24 \%$ sedang pada ibu bersalin usia $32-39$ tahun sebesar $62 \%$. Hasil penelitian terdahulu oleh Desi, 2011 pada bulan Januari-Maret 2011 di BPS Ny.Hanik Lutfiah Di Sidoarjo terdapat 68 (76\%) ibu yang mengalami ruptur perineum

spontan dari 87 ibu yang menjalani proses persalinan normal dan 19 (24\%) ibu diantaranya tidak mengalami ruptur perineum. Berdasarkan survei awal yang saya laukan sebagai peneliti pada bulan Mei 2013 di BPS Ny. Lilik Farida Kedurus Sidoarjo angka robekan perineum yang dialami oleh ibu bersalin pada bulan Januari-Maret 2013 berdasarkan data rekam medik yaitu dari 68 persalinan sebanyak $41(60 \%)$ ibu mengalami ruptur. Dari 41 ibu yang mengalami ruptur $21 \mathrm{ibu}$ mengalami ruptur spontan dan 20 ibu mangalami episiotomi. Sedangkan yang tidak mengalami ruptur perineum berjumlah $27(40 \%)$ ibu.

Pada proses persalinan terdapat faktor yang berperan terhadap terjadinya ruptur perineum yaitu kepala janin terlalu cepat lahir, persalinan tidak dipimpin sebagaimana mestinya, pada persalinan dengan distosia bahu, sudut arcus pubis lebih kecil, sebelumya pada perineum terdapat banyak jaringan parut, partus presipitatus, janin besar, abnormali konginetal seperti hydrocephalus, pada presentasi defleksi (dahi, muka) dan paritas. Pada dasarnya otot perineum memiliki batas ambang untuk meregang dengan maksimal, jika otot perineum meregang melebihi batas maksimalnya, hal ini akan menyebabkan sobeknya otot perineum yang meluas dan berbahaya sehingga ruptur perineum tidak dapat dihindari lagi (Prawirohardjo, 2007).

Ruptur perineum dapat menimbulkan perdarahan, infeksi serta gangguan rasa ketidaknyamanan. Perdarahan yang banyak terjadi pada ruptur perineum derajat dua dan derajat tiga atau jika ruptur meluas kesamping atau naik ke 
vulva di sekitar introitus vagina sampai mengenai klitoris (Prawirohardjo, 2007). Luka perineum mudah terjadi infeksi karena secara anatomi letaknya $1 \mathrm{~cm}$ di atas anus sehingga memungkinkan terkontaminasi feses. Infeksi juga menyebabkan luka tidak segera menyatu sehingga secara estetis kemaluan menjadi kurang baik, sehingga menimbulkan ketidaknyamanan bagi ibu.

\section{METODE PENELITIAN}

Desain penelitian yang digunakan adalah analitik dengan pendekatan yang digunakan adalah cross sectional, yaitu suatu penelitian dimana variabel independen (berat bayi lahir) dan dependen (robekan/ruptur perineum) diobservasi pada waktu yang sama.

Populasi dalam penelitian adalah seluruh ibu bersalin fisiologis di RB Lilik Kedurus Sidoarjo pada bulan Juni 2013 sebesar 27 orang. Sampel adalah sebagian ibu bersalin fisiologis di RB Lilik Kedurus Sidoarjo pada bulan Juni 2013 sebesar 25 orang. Tehnik sampling dilakukan secara probability sampling dengan teknik simple random sampling dimana semua subyek mempunyai kesempatan yang sama untuk dijadikan sampel dengan cara acak.

Variabel independen yaitu robekan perineum dan variable dependen berat bayi lahir. Instrumen yang digunakan alat pengukur berat badan. Cara pengumpulan data dengan observasi luka robekan perineum dan denfan menimbang berat badan bayi segera setelah persalinan

Data dianalisis dengan menggunakan uji statistik Mann-whtney dengan menggunakan SPSS for Windows dan tingkat signifikasi $\alpha=0,05$. Ho ditolak bila $\mathrm{p}<\alpha$ yang berarti ada hubungan antara berat badan bayi lahir dengan ruptur perineum.

\section{HASIL \& PEMBAHASAN}

\section{a. Hasil \\ Data Umum}

Data umum ini menggambarkan karakteristik responden di RB Lilik Kedurus Sidoarjo meliputi usia, dan paritas ibu. Dari 25 responden yang terkumpul kemudian di olah dan di kelompokkan sebagai berikut :

Karakterisrik responden berdasarkan umur

Karakteristik responden berdasar umur ideal seorang wanita untuk hamil dapat dilihat pada tabel berikut

Tabel 1 Distribusi frekuensi responden berdasarkan usia pada ibu yang bersalin secara fisiologis di RB Lilik Kedurus Sidoarjo.

\begin{tabular}{lcr}
\hline Umur & Frekuensi & persentase \\
\hline$<20$ & 2 & 8 \\
\hline $20-35$ & 20 & 80 \\
\hline$>35$ & 3 & 12 \\
\hline Total & 25 & 100 \\
\hline
\end{tabular}

Sumber: Data Sekunder, 2013

Berdasarkan hasil tabulasi tabel 5.1 menunjukkan bahwa dari 25 responden hampir seluruhnya ( $80 \%)$ berusia $20-35$ tahun.

Karakteristik Paritas Responden

Karakteristik responden berdasarkan paritas dapat dilihat pada tabel berikut ini

Tabel 2 Distribusi frekuensi responden bedasarkan paritas ibu bersalin di RB Lilik Kedurus Sidoarjo

\begin{tabular}{lcr}
\hline Paritas & Frekuensi & persentase \\
\hline Pprimipara & 13 & 52 \\
\hline Multipara & 11 & 44 \\
\hline Grandemultipara & 1 & 3 \\
\hline Total & 25 & 100 \\
\hline
\end{tabular}

Sumber: Data Sekunder, 2013

Berdasarkan hasil tabulasi tabel 2 dapat diketahui dari 25 responden sebagian besar (52\%) merupakan primipara. 
Karakteristik Kenaikan Berat Badan Selama Hamil

Tabel 3 Distribusi frekuensi responden bedasarkan kenaikan berat badan selama hamil ibu bersalin di RB Lilik Kedurus Sidoarjo.

\begin{tabular}{lcr}
\hline $\begin{array}{l}\text { Peningkatan } \\
\text { BB }\end{array}$ & Frekuensi & persentase \\
\hline$<6,5 \mathrm{~kg}$ & 4 & 16 \\
\hline $6,5-16 \mathrm{~kg}$ & 21 & 84 \\
\hline$>16 \mathrm{~kg}$ & 0 & 0 \\
\hline Total & 25 & 100 \\
\hline
\end{tabular}

Sumber : Data Sekunder, 2013

Dari hasil tabulasi tabel 3 dapat diketahui dari 25 responden hampir seluruhnya $(84 \%)$ mengalami kenaikan berat badan dalam batas yang normal yaitu $6,5-16 \mathrm{~kg}$.

Karakteristik Pekerjaan Responden

Karakteristik responden berdasarkan pekerjaan dapat dilihat pada tabel berikut

Tabel 4 Distribusi frekuensi responden bedasarkan pekerjaan ibu bersalin di RB Lilik Kedurus Sidoarjo.

\begin{tabular}{lcr}
\hline Usia & Frekuensi & persentase \\
\hline Tidak bekerja & 10 & 40 \\
\hline Bekerja & 15 & 60 \\
\hline Total & 25 & 100 \\
\hline
\end{tabular}

Sumber : Data Sekunder, 2013

Berdasarkan hasil tabulasi tabel 5.4 dapat diketahui dari 25 responden sebagian besar (60\%) bekerja.

Data Khusus

Karakteristik responden berdasarkan robekan perineum pada persalinan

Tabel 5 Distribusi responden berdasarkan robekan perineum pada ibu bersalin di RB Lilik Kedurus Sidoarjo.

\begin{tabular}{lll}
\hline $\begin{array}{l}\text { Robekan } \\
\text { perineum }\end{array}$ & frekuensi & persentase \\
\hline Tidak robekan & 10 & $40 \%$ \\
\hline Robekan & 15 & $60 \%$ \\
\hline Total & 25 & $100 \%$ \\
\hline
\end{tabular}

Sumber : data primer 2013

Berdasarkan hasil tabulasi tabel 2 dapat diketahui dari 25 responden ibu bersalin di RB Lilik Kedurus Sidoarjo sebagian besar (60\%) mengalami ruptur perineum.

Karakteristik responden berdasarkan berat bayi saat lahir

Tabel 6 Distribusi responden berdasarkan berat bayi saat lahir di RB Lilik Kedurus Sidoarjo.

\begin{tabular}{lcc}
\hline Berat Bayi (gram) & Frekuensi & persentase \\
\hline Kurang $(<2500)$ & 7 & $28 \%$ \\
\hline $\begin{array}{l}\text { Normal }(2500- \\
\text { 4000) }\end{array}$ & 18 & $72 \%$ \\
\hline Lebih (> 4000) & 0 & $0 \%$ \\
\hline Total & 25 & $100 \%$ \\
\hline
\end{tabular}

Sumber : data primer 2013

Berdasarkan hasil tabulasi tabel 2 dapat diketahui dari 25 responden ibu bersalin di RB Lilik Kedurus Sidoarjo sebagian besar $(72 \%)$ ibu melahirkan bayi dengan berat badan normal.

Hubungan antara berat badan bayi lahir dengan ruptur perineum

Tabel 7. Hubungan antara berat badan bayi lahir dengan ruptur perineum di RB Lilik Kedurus Sidoarjo.

\begin{tabular}{lccccrr}
\hline BB lahir & \multicolumn{2}{l}{ BB } & \multicolumn{2}{l}{ BB } & \multicolumn{2}{c}{ Total } \\
& \multicolumn{2}{c}{ Kurang } & \multicolumn{2}{l}{ Normal } & & \\
\hline Perineum & $\mathrm{f}$ & $\%$ & $\mathrm{f}$ & $\%$ & $\mathrm{f}$ & $\%$ \\
\hline $\begin{array}{l}\text { Tidak } \\
\text { robekan }\end{array}$ & 6 & 60,0 & 4 & 40, & 10 & 10 \\
& & & & 0 & & 0
\end{tabular}

\begin{tabular}{llllllr}
\hline Robeka & 1 & & 14 & 93, & 15 & 10 \\
$\mathrm{n}$ & & 6,7 & & 3 & & 0 \\
\hline
\end{tabular}




\begin{tabular}{lrrrrrr}
\hline Total & 7 & 28,0 & 18 & $\begin{array}{c}72, \\
0\end{array}$ & 25 & $\begin{array}{r}10 \\
0\end{array}$ \\
\hline
\end{tabular}

Berdasar tabel 3 dapat dilihat bahwa dari 25 responden didapatkan 15 responden yang mengalami robekan perineum, hampir seluruhnya $(93,3 \%)$ melahirkan bayi dengan berat badan normal, sedangkan dari 10 responden yang tidak mengalami robekan perineum, sebagian besar (60\%) melahirkan bayi dengan berat badan kurang.

Hasil uji mann whitney didapatkan nilai $\rho=0,004$ dengan $\alpha=0,05$ berarti $\rho<\alpha$ maka $\mathrm{H}_{0}$ ditolak berarti ada hubungan antara berat badan bayi lahir dengan ruptur perineum.

\section{b. Pembahasan}

\section{Berat Bayi Lahir}

Berdasarkan tabel 5 menunjukkan bahwa dari 25 ibu pada persalinan normal di RB Lilik sebagian besar (72\%) melahirkan dengan berat badan normal 2500-4000 gram. Berat bayi lahir di pengaruhi oleh status gizi ibu saat hamil. Hasil ini sesuai dengan teori Saifuddin (2002), yang mengatakan bahwa rata - rata bayi cukup bulan pada waktu lahir mempunyai berat badan normalnya, mencapai 2500 - 4000 gram. Tetapi ada beberapa responden yang melahirkan bayi dengan berat badan $<2500$ gram, hal ini bisa dipengaruhi oleh beberapa faktor misalnya: kenaikan berat badan selama hamil dan pekerjaan responden.

Pada hasil penelitian didapatkan pula bahwa dari 25 responden hampir seluruhnya (84\%) mengalami kenaikan berat badan selama hamil antara 6,5-16 kg. Selama hamil ibu akan mengalami kenaikan berat badan dan kenaikan berat badan ibu selama hamil dikatakan normal jika mengalami kenaikan antara 6,5-16 kg. Makanan yang di konsumsi saat hamil secara otomatis akan di konsumsi juga janin yang ada di dalam kandungannya sehingga akan mempengaruhi berat bayi saat lahir, selain itu juga akan mempengaruhi berat badan ibu selama hamil. Selama hamil ibu harus mengkonsumsi makanan yang bergizi karena akan mempengaruhi gizi pada janinnya. Jika ibu ingin melahirkan bayi dengan berat normal yaitu 25004000 gram maka ibu selama hamil harus mengalami kenaikan berat badan antara 6,5-16 kg. Hal ini sesuai dengan teori Winjosastro (2005) selama hamil ibu harus mengalami kenaikan berat badan yang berkisar antara $6,5-12 \mathrm{~kg}$.

\section{Ruptur Perineum}

Berdasarkan

Tabel 6

menunjukkan bahwa dari 25 ibu pada persalinan normal didapatkan hampir seluruhnya (60\%) mengalami ruptur perineum. Selain karena faktor berat bayi lahir tingginya robekan perenium ini dipengaruhi oleh beberapa faktor lain misalnya: paritas dan umur ibu.

Usia ibu yang melahirkan di RB Lilik Sidoarjo hampir seluruhnya (80\%) berusia 20-35 tahun dan pada usia ini adalah usia yang baik untuk proses melahirkan sehingga dapat minimalkan terjadinya ruptur perineum. Usia yang dapat menyebabkan ruptur adalah $<20$ tahun dimana kondisi ruptur masih matur sehingga mudah terjadi ruptur saat persalinan dan $>35$ tahun dimana kondisi ruptur sudah terlalu kaku sehingga susah terjadi peregangan maksimal saat persalinan sehingga mudah terjadi ruptur.

Faktor lain yang menyebabkan robekan perenium adalah paritas, sesuai dengan hasil penelitian di dapatkan sebagian besar (52\%) ibu bersalin adalah primipara. Robekan perineum pada primipara terjadi karena kurang elastisnya otot perineum pada saat proses persalinan sebab, jalan lahir ibu belum pernah dilewati oleh janin sehingga membutuhkan adaptasi dengan 
kondisi tersebut. Bentuk dari tidak adaptasinya jalan lahir terhadap janin pada saat proses pengeluaran janin adalah perineum tidak dapat mempertahankan tegangan yang kuat pada saat kepala keluar pintu sehingga robekan perineum tidak dapat dihindari lagi. Ini sesuai dengan teori yang dikemukakan oleh Sarwono (2005) bahwa pada primipara yang melahirkan bayi cukup bulan, perlukaan jalan lahir tidak dapat dihindarkan. Menurut Wikjosastro (2007) bahwa lapisan mukosa dan kulit perineum pada seorang ibu primipara mudah terjadi ruptur.

\section{Hubungan berat bayi lahir dengan robekan perineum}

Setelah dilakukan tabulasi silang antara kedua variabel yaitu berat badan bayi lahir dengan robekan perineum dan dari penghitungan uji statistik mannWhitney menunjukkan $\rho=0,004$ dengan tingkat kemaknaan $\alpha=0,05$ berarti $\rho<\alpha$ maka H0 ditolak berarti ada hubungan antara berat badan bayi lahir dengan ruptur perineum pada persalinan fisiologis, tetapi berat bayi lahir bukan faktor satu-satunya penyebab terjadinya ruptur perineum karena ada faktor lain yang mempengaruhinya yaitu faktor usia dan paritas. Dari hasil penelitian diketahui bahwa robekan perineum sesuai dengan berat badan bayi yang dilahirkan. Hal ini sesuai dengan teori dari Prawirohardjo (2007) yang menyatakan bahwa pada saat persalinan berat badan bayi lahir berpengaruh pada peregangan perineum.

Berdasarkan tabel 7 dijelaskan dari 25 ibu persalinan normal, ada 18 (72\%) responden yang melahirkan bayi dengan berat badan bayi lahir normal, sebagian besar mengalami ruptur perineum. Pada bayi lahir dengan berat badan $<2500$ gram pada umumnya tidak menimbulkan robekan jalan lahir akan tetapi ruptur masih terjadi hal ini menunjukkan bahwa berat bayi lahir bukan satusatunya faktor penyebab terjadinya ruptur pada perineum.

Terjadinya ruptur perineum dapat dicegah atau dikurangi dengan melakukan latihan senam hamil atau senam dasar panggul selama kehamilan dan sebelum persalinan, karena dapat meningkatkan kekuatan dan kelenturan otot-otot dasar panggul, ligamen, dan jaringan serta fasia yang berperan dalam mekanisme persalinan (Schott, 2008). Pimpinan persalinan untuk mengejan secara benar sangat menentukan sampai seberapa jauh terjadi perlukaan pada perineum (Prawirohardjo, 2007). Menjalin kerjasama dengan ibu dan menggunakan perasat manual yang tepat akan bermanfaat saat kepala bayi pada diameter 5-6 cm tengah membuka vulva atau crowning karena pengendalian kecepatan dan pengaturan diameter kepala saat melewati introitus dan perineum dapat mengurangi kemungkinan terjadinya robekan (Affandi, 2008).

\section{SIMPULAN}

Ibu yang bersalin secara fisiologis di RB Lilik Kedurus Sidoarjo sebagian besar melahirkan bayi dengan berat badan bayi lahir normal.

Ibu yang bersalin secara fisiologis di RB Lilik Kedurus Sidoarjo sebagian besar mengalami ruptur perineum.

Ada hubungan berat badan bayi lahir dengan ruptur perineum pada persalinan fisiologis di RB Lilik Kedurus Sidoarjo akan tetapi berat bayi lahir bukan satusatunya faktor penyebab terjadinya ruptur perenium karena ada faktor lain yang menyebabkan robekan perineum yaitu paritas dan usia ibu.

DAFTAR PUSTAKA

Afandi, Biran (2008). Buku Acuan dan Panduan Asuhan Persalinan 
Normal dan Inisiasi menyusu Dini. Jakarta: JHPIEGO

Arikunto, Suharsimi (2010). Prosedur penelitian Suatu Pendekatan Praktik. Jakarta:Rineka Cipta

Cuninngham F, Gery (2005). Obstetri Williams vol.2 edisi 21. Jakarta: EGC

Depkes RI (2004). Upaya Akselerasi penurunan Angka Kematian Ibu. www.depkes.go.id

Desi Putri (2011). Hubungan Berat Badan Bayi Lahir dengan Ruptur Perineum Spontan di Puskesmas

Hidayat, A.A (2009). Metode Penelitian Keperawatan Teknis Analisis Data. Jakarta: Salemba Medika

Liu David.T.Y (2007). Manual Persalinan edisi 3. Jakarta: EGC

Medford, Janet (2011). Kebidanan Oxford dan Bidan untuk Bidan. Jakarta: EGC

Prawiroharjo sarwono (2007). Ilmu Kebidanan. Jakarta :Yayasan Bina Pustaka- Sarwono Prawiroharjo

Rohani, Reni Saswita ,Marisah (2011). Asuhan Kebidanan pada Masa Persalinan. Jakarta: Salemba Medika

Rusda, Mohammad (2008). Jenis-Jenis Ruptur. www.Librery.usu.ac.id

Saifudin, Abdul Bari (2006). Buku Panduan Praktis Pelayanan Kesehatan Maternal dan neonatal. Jakarta :Yayasan Bina PustakaSarwono Prawiroharjo

Schoot, Judith. Judy priest (2008). Seri Praktek kebidanan Kelas Antenatal edisi 2. Jakarta: EGC

Simkin, Penny dkk (2007). Panduan Lengkap Kehamilan, Melahirkan dan Bayi. Jakarta: ARCAN

Sloalone, ethel (2004). Anatomi dan Fisiologi untuk pemula. Jakarta: ECG

Surasmi, Arsining.dkk (2005). Perawatan Bayi Resiko Tinggi. Jakarta: ECG
Tiran, Denise (2005). Kamus Saku Bidan edisi 10. Jakarta: ECG

Varney, H.dkk (2007). Buku Ajar Asuhan Kebidanan edisi 4. Jakarta: EGC

Winkjasastro, H (2005). Ilmu kandungan. Jakarta :Yayasan Bina Pustaka- Sarwono Prawiroharjo 